\title{
B1
}

doi: 10.14232/fgykf.2018.b1

\section{Antiproliferative and cytotoxic activities of furocoumarins of Ducrosia anethifolia}

Javad Mottaghipisheh, ${ }^{1}$ Márta Nové, Gabriella Spengler, ${ }^{2}$ Norbert Kúsz, ${ }^{1,3}$ Judit Hohmann, ${ }^{1,3}$ Dezsö Csupor ${ }^{1,3}$

${ }^{1}$ University of Szeged, Department of Pharmacognosy, 6720 Szeged, Eötvös u. 6.

${ }^{2}$ University of Szeged, Department of Medical Microbiology and Immunobiology, 6720 Szeged, Dóm tér 10.

${ }^{3}$ University of Szeged, Interdisciplinary Centre for Natural Products, 6720 Szeged, Eötvös u. 6.

Ducrosia anethifolia (DC.) Boiss. (Apiaceae) has been widley used in Iranian folk medicine. Based on literature data, furocoumarins are characteristic secondary metabolites of $D$. anethifolia. This work isolates and identifies the secondary metabolites from $D$. anethifolia and to study their antitumor and anti-multidrug resistance (MDR) activities. The $\mathrm{CHCl}_{3}$ extract of the aerial parts was subjected to various chromatographic methods to isolate pure constituents. Structure elucidation of the compounds was performed by means of NMR experiments. Antiproliferative and cytotoxic activities of the isolated furocoumarins, as the main compounds, were tested on multidrug resistant and sensitive mouse L51787Y mouse T-lymphoma cell lines and the $I_{50}$ values were determined. The inhibition of the cancer MDR efflux pump ABCB1 was evaluated by flow cytometry (at concentrations 2 and $20 \mu \mathrm{M}$ ). A checkerboard microplate method was applied to study the interactions of furocoumarins and doxorubicin. Thirteen pure compounds were isolated, nine furocoumarins namely, pabulenol (1), aviprin (2), oxypeucedanin (3), oxypeucedanin methanolate (4), prangol (5), imperatorin (6), isogospherol (7), heraclenin (8), heraclenol (9), along with vanillic aldehyde (10), harmine (11), 3-hydroxy- $\alpha$-ionone (12), and 2-C-methyl-erythrytol (13). Oxypeucedanin showed the highest in vitro antiproliferative and cytotoxic activity against parent $\left(\mathrm{IC}_{50}=25.98 \pm 1.27,40.33 \pm 0.63\right.$ $\mu \mathrm{M})$ and multidrug resistant $\mathrm{L} 5178 \mathrm{Y}$ mouse $\mathrm{T}$-cell lymphoma cells $\left(\mathrm{IC}_{50}=28.89 \pm 0.73\right.$, $66.68 \pm 0.00 \mu \mathrm{M})$, respectively. Compounds $2,3,5,7,10-13$ were identified for the first time from the Ducrosia genus. Oxypeucedanin is a promising compound for further investigations for its anticancer effects.

Supervisor: Dezső Csupor 